признаки гибели от поражения яиц микрофлорой и грибами. В контрольной группе такие признаки имели 64,3\% задохликов, в первой опытной - 53,8 \%, во второй опытной группе - 33,3\%, что также доказывает эффективность применяемых средств.

Ключевые слова: яйца уток, орошение, инкубация, дезинфекиионные средства, выводимость яиц.

\title{
FEATURES OF PROCESSING OF WATERFOWL EGGS DURING THE INCUBATION
}

Shomina N. V., Baydevlyatova O. M., State Poultry Research Station National Academy of Agrarian Sciences of Ukraine

The purpose of this work was to conduct a comparative evaluation of existing disinfectants for their use in the second half of incubation for irrigation of waterfowl eggs. Methods. The study was conducted at the State Poultry Research Station of NAAS on hatching eggs of ducks and incubation wastes. Pre-incubation disinfection of eggs was carried out by irrigation with 5.0\% solution of "Lasept-forte". Eggs were incubated according to standard regimes in modernized laboratory incubators ILU-F-0.3 and ILB-0.5. According to the requirements of the current standard for the technological process of incubation of duck eggs from the 13th day of incubation air cooling of eggs twice a day (morning and evening) for 10-15 minutes was carried out, and from the 20th day - a wet one. Modern disinfectants in various concentrations were used to irrigate duck eggs during incubation. Irrigation of duck eggs of the control group was performed with clean water. According to the results of research, the efficiency of irrigation of eggs with "Lasept-forte» and "Brovadez Plus» has been proved, and their optimal concentrations have been selected. It was found that the use of $0.5 \%$ "Lasept-forte" or $0.05 \%$ "Brovadez plus" for irrigation of duck eggs from the 20th day of incubation is desirable because it increases the results of incubation by $1.5-2.5 \%$ due to the improvement of the sanitary condition in the incubator and the reduction of embryo death in the later stages of development. The pathological autopsy of incubation wastes showed that the category of waste "dead" (embryos that died after 25 days of incubation) was in the control group at 7.0\%, in the experimental 6.0-6.5\%. At the same time, at the autopsy of the "dead" from these groups, there were signs of death from damage to eggs by microflora and fungi. In the control group, $64.3 \%$ of deaths had such symptoms, in the first experimental group - $53.8 \%$, in the second experimental group $33.3 \%$, which also proves the effectiveness of the means used.

Key words: duck eggs, watering, incubation, disinfectants, egg hatchability.

УДК 636.27.034.082.25(477)

DOI 10.32900/2312-8402-2020-124-232-245

\section{ЕФЕКТИВНІСТЬ РОЗВЕДЕННЯ ІНБРЕДНОЇ ХУДОБИ БІЛОГОЛОВОЇ УКРАЇНСЬКОЇ ПОРОДИ}

\author{
Войтенко С. Л., д. с.-Г. Н., професор \\ Сидоренко О. В., к. с.-Г. Н., с. н. с. \\ Інститут розведення і генетики тварин ім. М. В. Зубця НААН
}

Викладені результати використання аутбридингу та інбридингу при розведенні худоби білоголової української породи, яку відносять до локальних популя- 
цій та утримують лише в одному племінному стаді. Виявлено, щуо тварини, отримані від спорідненого розведення, характеризуються достатньо високим рівнем продуктивності та нормальними відтворювальними якостями. Аутбредні та інбредні телиці в прочесі росту від народження до 18-місячного віку хоча й дещо різнилися між собою за живою масою, але різниия була статистично недостовірною. В різні періоди росту перевагу мали як аутбредні, так і інбредні тварини, засвідчуючи можливість поліпшення ознаки методами чистопородного розведення. Абсолютний приріст живої маси піддослідних телищь на вирощуванні становив: I група - 295 кг, II - 289 кг, III - 298 кг, IV - 308 кг i V-293 кг без статистично достовірної різниці між групами, що дало підстави для висновку про можливість уникнення інбредної депресією в результаті використання при розведенні худоби даного стада спорідненого підбору батьківських пар. Визнано, щуо селекиія аутбредних та інбредних телят на збільшення живої маси при народженні здебільшого не матиме позитивного впливу на ознаку в процесі росту тварин з огляду на одержані корелячійні зв'язки між ними. За результатами вивчення відтворної здатності доведена доиільність отримання та використання інбредної худоби в стаді, яку осіменяли майже на місяџь раніме від аутбредної. Між аутбредними та інбредними різного ступеня інбридингу коровами виявлені значна диференціачія надою за першу-третю лактачію, без достовірної переваги тварин, одержаних тим чи іншим методом чистопородного розведення. 3 а першу лактацію найвищий надій молока мали корови групи тісного інбридингу (V група) - 4501 кг, які перевищували аутбредних на 150 кг та інбредних нижчих ступенів інбридингу (II - IV групи) на 191 - 633 кг. Інбредна худоба віддаленого, помірного та близького ступенів інбридингу за другу лактацію продукувала від 4629 кг до 4719 кг молока за найвищого показнику у корів помірного ступеня інбридингу, в той час як аутбредні корови - 4582 кг. Найвищі показники надою за третю лактацію мали корови помірного ступеня інбридингу - 5204 кг, а найнижчі - 3897 кг групи близького ступеня інбридингу. Аутбредні корови за даною ознакою переважали лише особин групи близького інбридингу. Одержані результати порівняльного аналізу господарськи корисних ознак аутбредних та інбредних корів і телиць білоголової украӥнської породи засвідчують можливість використання спорідненого підбору батьківських пар в стаді для підвищення ефективності внутрішньопородної селекиії, тиражування спадкових ознак родоначальника та $з$ метою збереження зникаючої вітчизняної породи великої рогатої худоби.

Ключові слова: скотарство, білоголова українська порода, методи розведення, ступінь інбридингу, корови, телиці, продуктивність.

За переконанням багатьох дослідників, селекційно-племінна робота 3 тваринами місцевих порід, поголів'я яких знаходиться під загрозою зникнення, передбачає використання методів чистопородного розведення, включаючи інбридинг, з огляду на біологічну складову цих методів - збереження і підсилення цінних властивостей родоначальника у поколіннях $[8,16,20]$. 3-поміж відомих методів чистопородного розведення найбільшу зацікавленість у дослідників викликає саме інбридинг, оскільки він консолідує популяцію за певними ознаками та тиражує цінні якості видатних предків [9, 13].

3'ясовано, що метод спорідненого розведення у сумі з жорстким добором сприяє виведенню тварин, здатних стійко передавати генетичний потенціал продуктивності своїм потомкам $[6,17,23]$. На особливу актуальність споріднене розведення, крім збереження біологічного різноманіття та унікальних якостей місце- 
вих порід сільськогосподарських тварин, заслуговує в процесі використання обмеженої кількості бугаїв-плідників, особливо голштинської породи, для відтворення маточного поголів'я корів. Впродовж 15 років генеалогічна однорідність бугаїв різних ліній української чорно-рябої молочної, української червоно-рябої молочної та української бурої молочної порід підвищилася на 35-45 \%, що змушує контролювати споріднене розведення та ураховувати ступінь інбридингу при підборі батьківських пар [21].

Дослідженнями вчених на худобі ярославської породи доведено, що в не численних локальних породах споріднене розведення може бути методом якісного удосконалення стада. 3'ясовано, що найвищий надій молока, вміст жиру та білку за найвищу лактацію одержано у групі чистопородних корів віддаленого ступеня інбридингу. Серед голштинизовних корів ярославської породи найвища молочна продуктивність одержана за поєднання батьківських пар віддаленого та помірного ступенів інбридингу [11].

В практиці тваринництва цілеспрямований інбридинг, особливо комплексний на групу предків, вважається ефективним прийомом селекційно-племінної роботи з породою. Такий метод сприяє витісненню небажаної спадковості та $є$ необхідним елементом створення нових порід чи перебудови існуючих [15]. За переконаннями ряду вчених, споріднене розведення, якщо його застосовувати непостійно і нестихійно, не приводить до негативних наслідків $[3,22]$ і навіть якщо не можна уникнути його систематичного використання, слід не допускати кровозмішування чи тісного інбридингу $[1,6,23]$. В свою чергу, за використання спорідненого розведення були одержані корови-рекордистки в симентальській породі, а поєднання інбредних тварин однієї лінії за внутрішньопородного підбору забезпечило покращення показників вмісту жиру й білку в молоці [5].

Визнано, що вплив інбридингу різних ступенів не приводить до істотної різниці живої маси корів, але інбредні самки, порівняно з аутбредним, народжували більше бугайців, ніж теличок. Найбільшу кількість молока за першу лактацію одержано від корів чорно-рябої голштинизованої худоби, ступінь інбридингу яких становить $12,5 \%$ [14].

При вивченні впливу ступеня інбридингу на молочною продуктивністю корів червоної степової породи з'ясовано, що найнижчий надій за першу і третю лактацію мали інбредні корови типу кровозмішування. Корови груп тісного і помірного інбридингу переважали аутбредних за надоєм першої і третьої лактації, при цьому найвищий надій за першу лактацію мали корови тісного інбридингу, а за третю лактацію - помірного [18].

Підтверджують думку про доцільність тривалого цілеспрямованого спорідненого розведення худоби української червоної молочної породи, крім варіанту тісного інбридингу, й результати досліджень інших науковців, які вважають, що інбридинг не порушує відтворювальних функцій корів, а навпаки, деякою мірою узгоджує розвиток їх продуктивних і репродуктивних ознак. Визнано, що для консолідації селекційних ознак у потомстві варто використовувати помірний інбридинг, а також враховувати розвиток стада та напрям селекції в ньому [19].

Проте навіть значна кількість наукових праць 3 позитивною оцінкою використання методу інбридингу при роботі з великою рогатою худобою не переконує практиків інтенсивно використовувати його в племінній роботі з різними породами. В процесі інтенсифікації галузі молочного скотарства у країнах з розвиненим скотарством відмічається негативний вплив спорідненого розведення на зниження генетичної мінливості основних селекційних ознак, особливо молочної продуктивності корів. Непоодинокі випадки народження телят з генетичними 
аномаліями $[10,24,26,27]$. Доведений зв'язок патологій у худоби різних порід із збільшенням ступеня інбридингу. Підвищення ступеня гомозиготності на 1 \% приводить до зменшення надою корів на 15,9 кг, виходу молочного жиру - на 1,37 кг, білку - 0,6 кг за одночасного збільшення тривалості сервіс - періоду на 1,96 днів, тяжкості отелень на 1,4\% та інших ознак продуктивності [25].

Із вищевикладеного видно, що проблема інбридингу складна й багатогранна, а ставлення до неї практиків і науковців здебільшого протилежне, що змушує постійно й конкретно в кожному стаді проводити пошук ефективних методів підбору корів і бугаїв для одержання потомства з бажаними ознаками продуктивності.

Нами у якості об'єкта досліджень вибрано білоголову українську породу великої рогатої худоби, яка була створена та використовувалася в переважній більшості в поліській кліматичній зоні $[2,3]$, в свій час слугувала основою для створення української чорно-рябої молочної породи [7], а в останні роки розводять переважно закритою популяцією [12]. Для збереження генофонду білоголової української породи рекомендовано використовувати методи внутрішньопородної селекції, а для підвищення молочної продуктивності корів повторювати вдалі поєднання батьківських пар, хоча при цьому й складно буде уникнути спорідненого розведення [4].

Враховуючи те, що худоба білоголової української породи залучена в процес виробництва молока й допомагає вирішити проблему забезпечення населення якісною продукцією тваринництва, метою роботи було вивчити господарськи корисні ознаки аутбредних та інбредних телиць і корів білоголової української породи, а також знайти способи збереження біорозмаїття популяції та ії̈ генетичної мінливості.

Матеріали та методи досліджень. Визначення впливу спорідненого та неспорідненого розведення на продуктивність тварин білоголової української породи проводили в умовах ТОВ «Подільський господар» Хмельницької області в рамках виконання НТП «Збереження генофонду сільськогосподарських тварин». Завданням досліджень передбачалося визначити можливість використання в процесі виробництва молока аутбредних та інбредних телиць і корів на основі порівняльного аналізу їх живої маси в процесі росту від народження до 18-місячного віку, показників відтворної здатності та молочної продуктивності за ряд лактацій.

Для досліджень були відібрані корови 2010-2014 рр. народження, яких використовували в стаді для виробництва молока до 2018 р. Тварини були аналогами за датою народження. Для проведення досліджень корови були розділені на 5 груп залежно від ступеня спорідненості та коефіцієнту інбридингу: I група - аутбредні; II група - коефіцієнт інбридингу $\mathrm{F}_{\mathrm{x}}=0,39-0,59 \%$ (віддалений ступінь); III група $-\mathrm{F}_{\mathrm{x}}=0,78-2,93 \%$ (помірний); IV група $-\mathrm{F}_{\mathrm{x}}=3,13-11,72 \%$ (близький) та $\mathrm{V}$ група $-\mathrm{F}_{\mathrm{x}}=12,5-29,7 \%$ (тісний). Ступінь інбридингу визначали за методом Шапоружа, а коефіцієнт інбридингу $\left(\mathrm{F}_{\mathrm{x}}\right)$ - за формулою С. РайтаКисловського [16]. Живу масу тварин визначали шляхом зважування в обумовлені вікові періоди. Надій молока корів за 305 днів першої лактації, їх вік першого осіменіння та отелення, а також живу масу в ці періоди визначали за використання матеріалів бази даних системи управління молочним скотарством (СУМС «Інтесел-Орсек») станом на 1 січня 2018 року. Статистичне опрацювання матеріалів досліджень зроблено за використання програмного пакету «STATISTICA 10.0» на ПК.

Результати досліджень. Нашими дослідженнями встановлено, що за однакового рівня годівлі й утримання аутбредні та інбредні телиці білоголової української породи дещо відрізнялися між собою за живою масою в різні періоди рос- 
ту, але ця різниця була статистично недостовірна (табл. 1). Найбільш масивними при народженні були тварини тісного ступеня інбридингу (V група), які переважали своїх аутбредних ровесниць на 4,0 кг, а 3 нижчим ступенем інбридингу (II IV групи) - на 3,0-5,0 кг за варіювання показнику живої маси серед усіх народжених телят у межах $29-34$ кг.

Таблиия 1

Зміни живої маси телиць у зв'язку з віком та ступенем інбридингу

$(\mathbf{M} \pm \mathbf{m}), \mathbf{\kappa} \Gamma$

\begin{tabular}{|c|c|c|c|c|c|c|c|c|}
\hline \multirow{2}{*}{$\begin{array}{c}\text { Групи за } \\
\text { ступенем } \\
\text { інбридингу }\end{array}$} & \multirow{2}{*}{$\begin{array}{c}\text { Пого- } \\
\text { лів'я, } \\
\text { гол. }\end{array}$} & \multicolumn{7}{|c|}{ Жива маса (кг) та вік тварин (міс) } \\
\hline & & $\mathbf{0}$ & 3 & 6 & 9 & 12 & 15 & 18 \\
\hline I аутбридинг & 58 & $\begin{array}{l}30 \pm \\
0,98\end{array}$ & $\begin{array}{l}68 \pm \\
2,58\end{array}$ & $\begin{array}{l}129 \pm \\
3,01\end{array}$ & $\begin{array}{l}182 \pm \\
4,56\end{array}$ & $\begin{array}{c}231 \pm \\
5,87\end{array}$ & $\begin{array}{l}282 \pm \\
7,17\end{array}$ & $\begin{array}{c}325 \pm \\
7,91\end{array}$ \\
\hline $\begin{array}{l}\text { II віддале- } \\
\text { ний }\end{array}$ & 18 & $\begin{array}{l}31 \pm \\
1,18\end{array}$ & $\begin{array}{l}74 \pm \\
3,94\end{array}$ & $\begin{array}{l}132 \pm \\
7,18\end{array}$ & $\begin{array}{l}182 \pm \\
10,57\end{array}$ & $\begin{array}{l}227 \pm \\
13,97\end{array}$ & $\begin{array}{l}268 \pm \\
14,56\end{array}$ & $\begin{array}{l}320 \pm \\
14,33\end{array}$ \\
\hline III помірний & 43 & $\begin{array}{l}29 \pm \\
0,91\end{array}$ & $\begin{array}{l}72 \pm \\
2,23\end{array}$ & $\begin{array}{l}136 \pm \\
4,51\end{array}$ & $\begin{array}{l}187 \pm \\
6,65\end{array}$ & $\begin{array}{l}233 \pm \\
7,99\end{array}$ & $\begin{array}{c}281 \pm \\
9,61\end{array}$ & $\begin{array}{l}327 \pm \\
9,97\end{array}$ \\
\hline IV близький & 64 & $\begin{array}{l}31 \pm \\
0,56\end{array}$ & $\begin{array}{l}74 \pm \\
1,91\end{array}$ & $\begin{array}{l}134 \pm \\
3,17\end{array}$ & $\begin{array}{l}187 \pm \\
4,68\end{array}$ & $\begin{array}{c}241 \pm \\
5,99\end{array}$ & $\begin{array}{c}291 \pm \\
7,78\end{array}$ & $\begin{array}{c}337 \pm \\
7,48\end{array}$ \\
\hline $\mathrm{V}$ тісний & 20 & $\begin{array}{l}34 \pm \\
1,81\end{array}$ & $\begin{array}{l}76 \pm \\
3,13\end{array}$ & $\begin{array}{l}126 \pm \\
4,09\end{array}$ & $\begin{array}{c}179 \pm \\
6,18\end{array}$ & $\begin{array}{c}231 \pm \\
9,6\end{array}$ & $\begin{array}{c}282 \pm \\
7,10\end{array}$ & $\begin{array}{c}327 \pm \\
6,19\end{array}$ \\
\hline
\end{tabular}

За живою масою у віці 3-х місяців аутбредні телята поступалися інбредним на 4,0 - 8,0 кг за найвищого показнику тісного ступеня інбридингу у групі. Різниця за живою масою у 6-місячному віці між аутбредними й інбредними телятами, крім групи тісного інбридингу, становила 3,0 - 7,0 кг. При цьому найбільша різниця відмічена між телятами, одержаними за неспорідненого підбору батьківських пар та спорідненого в типі помірного ступеня інбридингу. У цей віковий період телята тісного ступеня інбридингу (V група) почали відставати від представників 3 нижчим ступенем інбридингу на 6,0 - 10,0 кг та на 3,0 кг - від аутбредних.

У наступний період росту тварин - 9 місяців, аутбредні телиці за досліджуваною селекційною ознакою поступалися на 5,0 кг особинам помірного і близького ступеня інбридингу, але на 3,0 кг переважали тварин тісного інбридингу. Аналогічна ситуація отримана щодо живої маси піддослідних тварин у 12місячному віці, коли аутбредні телиці за живою масою на 2,0-10,0 кг поступалися представницям III і IV піддослідних груп, але були масивнішими на 4,0 кг за представниць II групи й знаходилися на рівні тварин V групи.

У віці 15 місяців піддослідні телиці теж не характеризувалися однорідністю досліджуваної ознаки. При цьому аутбредні телиці на 1,0 - 14,0 кг перевищували групу тварин віддаленого і помірного ступеня інбридингу, мали однакову живу масу з ровесниками групи тісного інбридингу, але поступалися на 9,0 кг особинам, ступінь інбридингу яких становив 3,13-11,72 \%. Заключний період вирощування телиць, який закінчується у віці 18 місяців, засвідчив вищу на 5,0 кг живу масу у аутбредних тварин лише порівняно з групою віддаленого ступеня інбридингу. 3 тваринами помірного, близького та тісного ступеня інбридингу у телиць не спорідненого розведення різниця становила 2,0; 12,0 і 2,0 кг, відповідно.

За результатами вивченої живої маси піддослідних тварин білоголової української породи зроблено висновок про відсутність негативного впливу спорідненого розведення на ріст тварин від народження до 18 місяців. В окремі вікові 
періоди аутбредний молодняк переважав інбредних тієї чи іншої групи, але різниця між ними була статистично недостовірною.

За період росту абсолютний приріст живої маси піддослідних тварин становив: I група - 295 кг, II - 289 кг, III -298 кг, IV - 308 кг і V - 293 кг, відповідно. Тобто, аутбредні телиці білоголової української породи за приростом живої маси під час вирощування переважали групу тварин віддаленого інбридингу (II група) на 6,0 кг і тісного (V група) - на 2,0 кг, але поступалися іншим групам на 3,0 13,0 кг без статистично достовірної різниці між групами.

3 метою визначення можливості добору телят за живою масою в ранньому віці нами встановлено співвідносну мінливість цієї селекційної ознаки у піддослідних тварин. Визначено, що селекція аутбредних та інбредних телят на збільшення живої маси при народженні здебільшого не матиме позитивного впливу на ознаку в процесі росту тварин $з$ огляду на одержані коефіцієнти кореляції. Так, у аутбредних телиць кореляційний зв'язок між живою масою при народженні та в подальші вікові періоди був низьким та середнім $(\mathrm{r}=+0,142 \ldots+0,308)$; у групі телиць віддаленого ступеня інбридингу - середній $(\mathrm{r}=+0,457 \ldots+0,601)$; помірного інбридингу - слабкий, але здебільшого прямий $(\mathrm{r}=-0,122 \ldots+0,487)$, за виключенням віку 3 місяців; серед тварин близького інбридингу - низький та середній (r $=+0,08 \ldots+0,344)$; а в групі тісного інбридингу - прямий і зворотний, слабкий, середній і сильний $(\mathrm{r}=-0,739 \ldots+0,739)$. Тобто, селекція на підвищення живої маси телиць при народженні, незалежно від того, аутбредні вони чи інбредні, не узгоджується з можливістю контролювання ознаки в процесі росту тварин.

Поза визначення живої маси телиць білоголової української породи, одержаних в результаті спорідненого та неспорідненого підбору батьківських пар, зацікавленість викликала й їх відтворювальна здатність, оскільки чим раніше тварини будуть залучені в процес виробництва молока, тим прибутковість господарства буде вищою. За показниками відтворювальної здатності піддослідних корів встановлено доцільність отримання та використання інбредної худоби, оскільки ії осіменяли майже на місяць раніше від аутбредної й закономірно перше отелення у неї відбувалося раніше від одержаної в результаті неспорідненого підбору батьківських пар. Як видно з таблиці 2, перше плідне осіменіння у аутбредних телиць (I група) відбувалося на 0,5-0,9 міс. пізніше, ніж у інбредних II - V груп. Серед інбредних телиць різного ступеня інбридингу вік першого осіменіння варіював у межах 19,4 -19,8 місяців і найвищим був у групі особин з віддаленим ступенем інбридингу.

Таблиия 2

\section{Вплив ступеня інбридингу на живу масу і вік корів за першого} осіменіння та отелення (M $\pm \mathbf{m})$

\begin{tabular}{|c|c|c|c|c|c|}
\hline \multirow{2}{*}{$\begin{array}{c}\text { Групи за сту- } \\
\text { пенем інбри- } \\
\text { дингу }\end{array}$} & \multirow{2}{*}{$\begin{array}{l}\text { Пого- } \\
\text { лів’я, } \\
\text { гол. }\end{array}$} & \multicolumn{2}{|c|}{ Жива маса тварин, кг } & \multicolumn{2}{|c|}{ Вік тварин, міс } \\
\hline & & $\begin{array}{l}\text { за першого } \\
\text { осіменіння }\end{array}$ & $\begin{array}{c}\text { за першого } \\
\text { отелення }\end{array}$ & $\begin{array}{l}\text { за першого } \\
\text { осіменіння }\end{array}$ & $\begin{array}{c}\text { за першого } \\
\text { отелення }\end{array}$ \\
\hline I аутбридинг & 58 & $20,3 \pm 0,68$ & $29,8 \pm 0,71$ & $350 \pm 9,87$ & $483 \pm 5,87$ \\
\hline II віддалений & 18 & $19,8 \pm 1,23$ & $29,2 \pm 1,31$ & $356 \pm 13,87$ & $448 \pm 10,68$ \\
\hline III помірний & 43 & $19,4 \pm 0,69$ & $28,8 \pm 0,73$ & $351 \pm 9,67$ & $491 \pm 28,82$ \\
\hline IV близький & 64 & $19,4 \pm 0,53$ & $28,2 \pm 0,79$ & $345 \pm 7,17$ & $519 \pm 21,3$ \\
\hline V тісний & 20 & $19,4 \pm 0,89$ & $29,3 \pm 1,24$ & $371 \pm 18,46$ & $506 \pm 30,37$ \\
\hline
\end{tabular}

Загалом, вік першого отелення у піддослідних корів узгоджувався з віком першого осіменіння за збереження загальної тенденції розподілу ознаки між гру- 
пами. Найвищий показник віку першого отелення встановлено у групі аутбредних корів - 29,2 місяців відповідно, що більше за інбредних тварин на 0,5-0,6 місяців. Проте й за цим показником між аутбредними та інбредними тваринами не було виявлено статистично достовірної різниці, яка б засвідчувала перевагу спорідненого чи неспорідненого розведення худоби білоголової української породи.

Жива маса піддослідних корів при першому осіменінні варіювала у межах 345-371 кг, а при першому отеленні - 448 - 519 кг без чіткої узгодженості із ступенем інбридингу.

Заключний висновок про ефективність використання чистопородного розведення, із застосуванням інбридингу різних ступенів, в стаді худоби локальної білоголової української породи зроблено за результатними молочної продуктивності аутбредних та інбредних корів за 305 днів їх першої-третьої лактації. За даними таблиці 3 встановлено, що за першу лактацію найвищий надій молока мали

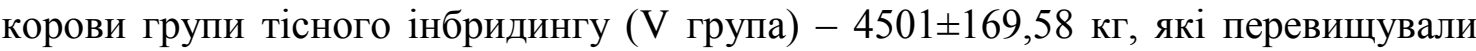
аутбредних на 150 кг та інбредних нижчих ступенів інбридингу (II - IV групи) на 191 - 633 кг. Аутбредні корови за першу лактацію характеризувалися вищою на 41 - 292 кг продуктивністю, порівняно до груп віддаленого, помірного і близького інбридингу, але поступалися представникам групи тісного інбридингу на 150 кг без статистичної достовірності між ними. За другу лактацію аутбредні корови I групи та інбредні II - IV груп значно підвищили свій надій, a V групи - навпаки, істотно знизили, що вплинуло на оцінку ефективності використання спорідненого розведення в стаді.

Таблиия 3

Надій аутбредних та інбредних корів (M $\pm \mathbf{m})$, кг

\begin{tabular}{|l|c|c|c|c|c|}
\hline \multirow{2}{*}{$\begin{array}{c}\text { Лакта- } \\
\text { ція }\end{array}$} & \begin{tabular}{c} 
Піддослідна група (ступінь інбридингу) \\
(аутбридинг) \\
\cline { 2 - 6 } (віддалений)
\end{tabular} & $\begin{array}{c}\text { III } \\
\text { (помірний) }\end{array}$ & $\begin{array}{c}\text { IV } \\
\text { (близький) }\end{array}$ & $\begin{array}{c}\text { V } \\
\text { (тісний) }\end{array}$ \\
\hline \multirow{3}{*}{ I } & $\mathrm{n}=61$ & $\mathrm{n}=18$ & $\mathrm{n}=43$ & $\mathrm{n}=64$ & $\mathrm{n}=21$ \\
\cline { 2 - 6 } & $4351 \pm 98,2$ & $4210 \pm 158,62$ & $\begin{array}{c}4310 \pm 116,3 \\
9\end{array}$ & $4059 \pm 99,9$ & $\begin{array}{c}4501 \pm 169,5 \\
8\end{array}$ \\
\hline \multirow{2}{*}{ II } & $\mathrm{n}=51$ & $\mathrm{n}=11$ & $\mathrm{n}=28$ & $\mathrm{n}=40$ & $\mathrm{n}=16$ \\
\cline { 2 - 7 } & $4582 \pm 146,89$ & $4629 \pm 214,78$ & $4719 \pm 214,37$ & $4660 \pm 141,89$ & $4213 \pm 306,94$ \\
\hline \multirow{2}{*}{ III } & $\mathrm{n}=23$ & $\mathrm{n}=5$ & $\mathrm{n}=12$ & $\mathrm{n}=6$ & $\mathrm{n}=7$ \\
\cline { 2 - 7 } & $4585 \pm 161,86$ & $5083 \pm 440,61$ & $5204 \pm 362,45$ & $3897 \pm 281,31$ & $4667 \pm 413,38$ \\
\hline
\end{tabular}

Аутбредні корови за надоєм другої лактації перевищували представниць групи тісного інбридингу на 369 кг, але водночас поступалися особинам II IV груп, відповідно, на 47, 137 і 78 кг без достовірної різниці між групами. В свою чергу інбредна худоба віддаленого, помірного та близького ступенів інбридингу продукувала за другу лактацію від 4629 кг до 4719 кг молока за найвищого показнику у корів помірного ступеня інбридингу. Тобто і за результатами надою корів за другу лактацію не можна зробити висновок про чітко обумовлений негативний вплив спорідненого розведення.

За третю лактацію між надоєм корів, одержаних за різних методів внутрішньопородного підбору, теж не встановлено закономірної переваги інбридингу над аутбридингом чи навпаки. У аутбредних корів, а також груп віддаленого та помірного інбридингу встановлена тенденція до збільшення надою з першої до третьої лактації, в той час як у групі близького та тісного інбридингу надій мав 
стрибкоподібний характер й не вирізнявся однорідністю, хоча можливо це й не обумовлювалося ступенем гомозиготності тварин. Загалом, найвищі показники надою за третю лактацію мали корови помірного ступеня інбридингу - 5204 кг, а найнижчі - 3897 кг, групи близького ступеня інбридингу. Аутбредні корови поступалися за досліджуваною ознакою представницям II, III та V груп на 498 кг, 619 кг і 82 кг, відповідно, але характеризувалися вищою продуктивністю порівняно до особин групи близького інбридингу. 3 огляду на наявність істотної міжгрупової різниці надою корів різних лактацій, відображеної у похибці показнику, нами не встановлено достовірної різниці між групами, яка б дозволила акцентувати увагу на спорідненому чи не спорідненому підборі тварин в стаді білоголової української породи.

Загалом, аналіз продуктивності худоби білоголової української породи дав змогу визначити, що споріднений підбір батьківських пар не знижує молочну продуктивність та відтворювальну здатність у потомків, порівняно з тваринами не спорідненого підбору. Тобто, в стаді білоголової української породи є інбредні корови, яких можна віднести до рекордисток та ввести до селекційної групи, але при цьому слід контролювати рівень та ступень інбридингу у потомства 3 тим, щоб не проявилися негативні наслідки спорідненого розведення у вигляді генетичних аномалій, нежиттєздатного потомства та низької продуктивності.

Подальші наукові дослідження з худобою української білоголової породи в контексті виконання програми «Збереження генофонду сільськогосподарських тварин» мають бути спрямовані на визначення гомозиготності тварин методами молекулярної генетики, а також продуктивності інбредних тварин в розрізі наявних ліній для подальшого використання лінійного розведення в закритій популяції.

\section{Висновки:}

1. За результатами вивченої живої маси піддослідних тварин білоголової української породи зроблено висновок про відсутність негативного впливу спорідненого розведення на ріст тварин від народження до 18 місяців. В окремі вікові періоди аутбредний молодняк переважав інбредних тієї чи іншої групи, але різниця між ними була статистично недостовірною.

2. Визначено, що селекція аутбредних та інбредних телят на збільшення живої маси при народженні здебільшого не матиме позитивного впливу на ознаку в процесі росту тварин з огляду на одержані коефіцієнти кореляції. Так, у аутбредних телиць кореляційний зв'язок між живою масою при народженні та в подальші вікові періоди був низьким та середнім $(\mathrm{r}=+0,142 \ldots+0,308)$; у групі телиць віддаленого ступеня інбридингу - середній $(\mathrm{r}=+0,457 \ldots+0,601)$; помірного інбридингу - слабкий, але здебільшого прямий $(\mathrm{r}=-0,122 \ldots+0,487)$, за виключенням віку 3 місяців; серед тварин близького інбридингу - низький та середній (r = $+0,08 \ldots+0,344)$; а в групі тісного інбридингу - прямий і зворотний, слабкий, середній і сильний $(\mathrm{r}=-0,739 \ldots+0,739)$.

3. Встановлено доцільність отримання та використання інбредної худоби, оскільки її осіменяли майже на місяць раніше від аутбредної й закономірно перше отелення у неї відбувалося раніше від одержаної в результаті неспорідненого підбору батьківських пар.

4. Встановлено ефективність використання чистопородного розведення, iз застосуванням інбридингу різних ступенів, в стаді худоби локальної білоголової української породи за результатними молочної продуктивності аутбредних та інбредних корів за 305 днів їх першої-третьої лактації. 


\section{Бібліографічний список}

1. Анисимова Е., Гостева Е. Эффективные приемы селекции симментальского скота. Молочное и мясное скотоводство. 2013. № 3. С. 19-21.

2. Бірюкова К. С. Білоголова українська порода. Племінна робота з породами великої рогатої худоби. Київ, 1963. С. 272-293.

3. Войтенко С. Л. Эффективность применения инбридинга в закрытой популяции свиней. Зоотехния. 2003. № 8. С. 13-14.

4. Войтенко С. Л. Можливість підвищення молочної продуктивності у корів локальних порід. Вісник Полтавської державної аграрної академії. Полтава, 2016. № 4. С. 72-75.

5. Кравченко Н. А. Винничук Д.Т., Гавриленко В. П., Павловский Г. А. Влияние инбридинга на молочную продуктвиность, впоспроизводительную способность и экстерьер коров-рекордисток симентальской породы. Молочно-мясное скотоводство : респуб. межведом. темат. науч. сб. Харьков, 1985. Вып. 66. C. $13-17$.

6. Зубець М. В. Буркат В. П., Сфіменко М. Я., Полупан Ю. П Генетика і селекція у скотарстві. Генетика і селекція в Украйні на межі тисячоліть. Київ : Логос, 2001. Т. 4. С. 181-198.

7. Зубец М. В., Буркат В. П., Мельник, Ю. Ф., Сфименко М. Я., Петренко И. П., Хаврук А. Ф. Генетика, селекция и биотехнология в скотоводстве. Киев : «БМТ», 1997. $722 \mathrm{c}$.

8. Гузєв I. В. Концептуальні основи збереження генофонду сільськогосподарських тварин в Україні. Проблеми збереження генофонду тварин : матеріали творч. дискусії / за ред. В. П. Бурката. Київ : Аграрна наука, 2007. С. 4-25.

9. Дунин И. М. Труфанов В. Г., Новиков Д. В. Использование инбридинга в молочном скотоводстве. Зоотехния. 2012. № 9. С. 2-3.

10. Жебровський Л. С. Селекція тварин. С.-Пб. : Лань, 2002. 256 с.

11. Зверева Е. А., Муравьева Н. А. Эффективность применения инбридинга при разведении коров ярославской породы. Международный научноисследовательский журнал. 2016. № 11 (53), ч. 5. С. 18-21. DOI: $10.18454 /$ IRJ.2016.53.121

12. Сфіменко М. Я., Порхун М. Г., Чехівський М. Й.,. Боярська А. В, Булка В. М. Стан збереження генофонду білоголової української породи на сучасному етапі. Розведення $i$ генетика тварин : міжвідом. темам. наук. зб. Київ, 2008. Вип. 42. С. $82-87$.

13. Костенко А. И., Серацкий И. 3., Меркушин В. В., Шапирко В. В. Инбридинг и племенная ценность быков-производителей / Цитология и генетика. 1994. Т. 28. № 1. С. $54-59$.

14. Климова С. П., Шендаков А. И., Шендакова Т. А. Влияние степеней инбридинга на молочную продуктивность черно-пестрого голштинизированного скота. Вестник орловского государственного аграрного университета. 2012. № 4 (12). С. $86-89$

15. Кравченко М. А. Теоретичні основи розведення тварин по лініях. Тваринництво України. 1969. № 11. С. 17-19.

16. Красота В. Ф. Лобанов В. Т., Джапаридзе Т. Г. Разведение сельскохозяйственных животных. Москва : Агропромиздат, 1990. 463 с.

17. Ладика В. І. Ефективність спорідненого спарювання в селекції бугаївплідників бурих порід. Вісник аграрної науки. 1998. № 6. С. 52-54. 
18. Микитас Р. С., Демчук В. В., Папакіна Н. С. Прогнозування молочної продуктивност корів червоної степової породи різного ступеня інбридингу. Таврійський науковий вісник. 2001. Вип. 17. С. 59-62.

19. Підпала Т. В. Породотворний процес та інбридинг у молочному скотарстві. Розведення і генетика тварин. Київ, 2007. Вип. 41. С. 164-171.

20. Гладій М. В. Полупан Ю. П., Басовський Д. М., Вишневський Л. В., Ковтун С. І., Сидоренко О. В Програма збереження генофонду локальних і зникаючих порід сільськогосподарських тварин в Україні на 2017-2025 роки. Суми, $2018.84 \mathrm{c}$.

21. Рудик I. А., Ставецька Р. В. Консолідованість та спорідненість ліній голштинської породи в Україні. Технологія виробництва $і$ переробки продукції тваринництвва. Біла Церква, 2010. Вип. 3 (72). С. 3-8.

22. Солдатов А. П., Сперанский А. Г. Влияние инбридинга на молочную продуктивность крупного рогатого скота швицкой породы. Генетические основы повышения продуктивности сельскохозяйственных животных : сб. науч. тр. Всесоюзного сельскохозяйственного института заочного образования. Москва, 1975. Вып. 96. С. 15-21.

23. Петренко І. П., Зубець М. В., Буркат В. П., Петренко А. П. Теорія системного аналізу «кровозмішення» у тварин. Київ : Аграрна наука, 2005. 521 с.

24. Croquet, C., Mayeres, P., Gillon, A., Vanderick, S., \& Gengler, N. (2006). Inbreeding depression for global and partial economic indexes, production, type, and functional traits. Journal of dairy science, 89(6), 2257-2267. https://doi.org/10.3168/jds.S0022-0302(06)72297-4.

25. Evaluation of inbreeding depression in Holstein cattle using whole-genome SNP markers and alternative measures of genomic inbreeding. D. W. Bjelland, K. A. Weigel, N. Vukasinovic, J. D. Nkrumah Journal of Dairy Science. 2013. Vol. 96. Is. 7. P. 4697-4706

26. Rokouei, M., Vaez Torshizi, R., Moradi Shahrbabak, M., Sargolzaei, M., \& Sørensen, A. C. (2010). Monitoring inbreeding trends and inbreeding depression for economically important traits of Holstein cattle in Iran. Journal of Dairy Science, 93(7), 3294-3302. DOI:10.3168/jds.2009-2748.

27. Smith L. A., Cassell B. G., Pearson R. E. The effects of inbreeding on the lifetime performance of dairy cattle. Journal of Dairy Science. 1998. Vol. 81, Is. 10. P. 2729-2737.

\section{References}

1. Anisimova, Ye., \& Gosteva Ye. (2013). Effektivn·yye priyemy selektsii simmental'skogo skota [Effective methods of breeding Simmental cattle]. Molochnoye $i$ myasnoye skotovodstvo - Dairy and beef cattle farming, 3, 19-21 [in Russian].

2. Biriukova, K. S. (1963). Biloholova ukrainska poroda [Ukrainian Whiteheaded breed]. Pleminna robota z porodamy velykoi rohatoi khudoby - Breeding work with breeds of cattle. (pp. 272-293). Kyiv [in Ukrainian].

3. Voytenko, S. L. (2003). Effektivnost' primeneniya inbridinga v zakrytoy populyatsii sviney [The effectiveness of inbreeding in a closed population of pigs]. Zootekhniya-Zootechniya, 8, 13-14 [in Russian].

4. Voitenko, S. L. (2016). Mozhlyvist pidvyshchennia molochnoi produktyvnosti $\mathrm{u}$ koriv lokalnykh pored [The ability to increase milk production in cows of local breeds]. Visnyk Poltavskoi derzhavnoi ahrarnoi akademii - Bulletin of Poltava State Agrarian Academy, 4, 72-75 [in Ukrainian]. 
5. Kravchenko, N. A., Vinnichuk, D. T., Gavrilenko, V. P., \& Pavlovskiy, G. A. (1985). Vliyaniye inbridinga na molochnuyu produktvinost', vposproizvoditel'nuyu sposobnost' i ekster'yer korov-rekordistok simental'skoy porody [Influence of inbreeding on milk production, reproductive ability and conformation of record-breaking cows of the Simmental breed]. Molochno-myasnoye skotovodstvo - Dairy and beef cattle Farming. Kharkiv, 66, 13-17 [in Russian].

6. Zubet, M. V. Burkat, V. P., Yefimenko, M. Ya., \& Polupan, Yu. P. (2001). Henetyka i selektsiia u skotarstvi [Genetics and selection in animal husbandry]. Henetyka i selektsiia v Ukraini na mezhi tysiacholit - Genetics and selection in Ukraine at the turn of the millennium. (Vols. 4), (pp. 181-198). Kyiv : Lohos [in Ukrainian].

7. Zubets, M. V., Burkat, V. P., Mel'nik, Yu. F., Yefimenko, M.Ya., Petrenko, I. P., \& Khavruk A.F. (1997). Genetika, selektsiya i biotekhnologiya v skotovodstve [Genetics, selection and biotechnology in cattle breeding]. Kyiv : BMT [in Russian].

8. Huziev, I. V. (2007). Kontseptualni osnovy zberezhennia henofondu silskohospodarskykh tvaryn v Ukraini [Conceptual foundations of conservation of the gene pool of farm animals in Ukraine]. Problemy zberezhennia henofondu tvaryn - Problems of preserving the gene pool of animals : materialy tvorch. dyskusii - creative materials. discussions (pp. 4-25). Kyiv : Ahrarna nauka [in Ukrainian].

9. Dunin, I. M., Trufanov, V. G., \& Novikov, D. V. (2012). Ispol'zovaniye inbridinga $\mathrm{v}$ molochnom skotovodstve [Use of inbreeding in dairy cattle breeding]. Zootekhniya - 'Zootechniya, 9, 2-3 [in Russian].

10. Zhebrovskyi, L. S. (2002). Selektsiia tvaryn [Selection of animals]. SanktPeterburg : Lan [in Ukrainian].

11. Zvereva, Ye. A., \& Murav'yeva, N. A. (2016). Effektivnost' primeneniya inbridinga pri razvedenii korov yaroslavskoy porody [Efficiency of inbreeding in breeding cows of the Yaroslavl breed.]. Mezhdunarodnyy nauchno-issledovatel'skiy zhurnalInternational research journal, 11 (53), 5, 18-21. DOI: 10.18454/IRJ.2016.53.121 [in Russian].

12. Yefimenko, M. Ya., Porkhun, M. H., Chekhivskyi, M. Y., Boiarska, A. V., \& Bulka, V. M. (2008). Stan zberezhennia henofondu biloholovoi ukrainskoi porody na suchasnomu etapi [The state of preservation of the gene pool of the Ukrainian Whiteheaded breed at the present stage] / Rozvedennia i henetyka tvaryn - Animal Breeding and Genetics. Kyiv. 42, 82-87 [in Ukrainian].

13. Kostenko, A. I., Siratskiy, I. Z., Merkushin, V. V., \& Shapirko, V. V. (1994). Inbriding i plemennaya tsennost' bykov-proizvoditeley [Inbreeding and breeding value of sire bulls] Tsitologiya i genetika - Cytology and genetics, 28, 1, 54 -59 [in Russian].

14. Klimova, S. P., Shendakov, A. I., \& Shendakova, T. A. (2012). Vliyaniye stepeney inbridinga na molochnuyu produktivnost' cherno-pestrogo golshtinizirovannogo skota [Influence of the degrees of inbreeding on the milk productivity of Blackand-White Holstein cattle]. Vestnik orlovskogo gosudarstvennogo agrarnogo universiteta - Bulletin of the Oryol State Agrarian University, 4 (12), 86-89 [in Russian].

15. Kravchenko, M. A. (1969). Teoretychni osnovy rozvedennia tvaryn po liniiakh [Theoretical foundations of animal breeding along the lines]. Tvarynnytstvo Ukrainy - Livestock of Ukraine, 11, 17-19 [in Ukrainian].

16. Krasota, V. F. Lobanov, V. T., \& Dzhaparidze, T. G. (1990). Razvedeniye sel'skokhozyaystvennykh zhivotnykh [Breeding of farm animals]. Moscow : Agropromizdat [in Russian].

17. Ladyka, V. I. (1998). Efektyvnist sporidnenoho spariuvannia v selektsii buhaiv-plidnykiv burykh porid [The efficiency of related mating in the selection of 
breeding bulls of brown breeds]. Visnyk ahrarnoi nauky - Bulletin of Agricultural Science, 6, 52-54 [in Ukrainian].

18. Mykytas, R. Ye., Demchuk, V. V., \& Papakina, N. S. (2001). Prohnozuvannia molochnoi produktyvnost koriv chervonoi stepovoi porody riznoho stupenia inbrydynhu [Prediction of milk productivity of cows of red steppe breed of different degree of inbreeding.]. Tavriiskyi naukovyi visnyk - Taurida Scientific Herald, 17, 5962 [in Ukrainian].

19. Pidpala, T. V. (2007). Porodotvornyi protses ta inbrydynh u molochnomu skotarstvi [Breeding process and inbreeding in dairy farming]. Rozvedennia i henetyka tvaryn - Animal Breeding and Genetics. Kyiv, 41, 164-171 [in Ukrainian].

20. Hladii, M. V., Polupan, Yu. P., Basovskyi, D. M., Vyshnevskyi, L. V., Kovtun, S. I., Sydorenko, O. V. (2018). Prohrama zberezhennia henofondu lokalnykh i znykaiuchykh porid silskohospodarskykh tvaryn v Ukraini na 2017-2025 roky [The program of preservation of the gene pool of local and endangered breeds of farm animals in Ukraine for 2017-2025]. Sumy [in Ukrainian].

21. Rudyk, I. A., \& Stavetska, R. V. (2010). Konsolidovanist ta sporidnenist linii holshtynskoi porody $\mathrm{v}$ Ukraini [Consolidation and cognation of Holstein breed lines in Ukraine]. Tekhnolohiia vyrobnytstva i pererobky produktsii tvarynnytstva - Animal Husbandry Products Production and Processing, 3 (72), 3-8 [in Ukrainian].

22. Soldatov, A. P., \& Speranskiy, A. T. (1975). Vliyaniye inbridinga na molochnuyu produktivnost' krupnogo rogatogo skota shvitskoy porody [The influence of inbreeding on dairy productivity of cattle of Swiss breed]. Geneticheskiye osnovy povysheniya produktivnosti sel'skokhozyaystvennykh zhivotnykh - Genetic bases of increase of productivity of farm animals. Moscow, 96, 15-21 [in Russian].

23. Petrenko, I. P., Zubets, M. V., Burkat, V. P., \& Petrenko, A. P (2005). Teoriia systemnoho analizu «krovozmishennia» $u$ tvaryn [Theory of system analysis of "incest" in animals]. Kyiv : Ahrarna nauka [in Ukrainian].

24. Croquet, C., Mayeres, P., Gillon, A., Vanderick, S., \& Gengler, N. (2006). Inbreeding depression for global and partial economic indexes, production, type, and functional traits. Journal of dairy science, 89 (6), 2257-2267. https://doi.org/10.3168/jds.S0022-0302(06)72297-4.

25. Bjelland, D. W., Weigel, K. A., Vukasinovic, N., \& Nkrumah, J. D. (2013). Evaluation of inbreeding depression in Holstein cattle using whole-genome SNP markers and alternative measures of genomic inbreeding. Journal of dairy science, 96 (7), 4697-4706. https://doi.org/10.3168/jds.2012-6435.

26. Rokouei, M., Vaez Torshizi, R., Moradi Shahrbabak, M., Sargolzaei, M., \& Sørensen, A. C. (2010). Monitoring inbreeding trends and inbreeding depression for economically important traits of Holstein cattle in Iran. Journal of Dairy Science, 93(7), 3294-3302. DOI:10.3168/jds.2009-2748.

27. Smith, L. A., Cassell, B. G., \& Pearson, R. E. (1998). The Effects of Inbreeding on the Lifetime Performance of Dairy Cattle. Journal of Dairy Science, 81(10), 2729-2737. DOI:10.3168/jds.s0022-0302(98)75830-8.

ЭФФЕКТИВНОСТЬ РАЗВЕДЕНИЯ ИНБРЕДНОГО

CKOTA БЕЛОГОЛОВОЙ УКРАИНСКОЙ ПОРОДЫ

Войтенко С. Л., Сидоренко Е. В., Институт разведения и генетики животных им. М. В. Зубиза НААН

Изложены результаты использования аутбридинга и инбридинга при разведении белоголовой украинской породы, которая относится к локальной популяции и содержат только в одном племенном стаде. Выявлено, что животные, по- 
лученные от родственного разведения, характеризуются достаточно высоким уровнем производительности и нормальными воспроизводственными качествами. Аутбредные и инбредные телки в процессе роста от рождения до 18 месячного возраста хотя несколько и отличались между собой по живой массе, но разница была статистически недостоверной. В отдельные периоды роста преимущество имели как аутбредные, так и инбредные животные, указывая на возможность улучшения признака методами чистопородного разведения. Абсолютный прирост живой массы подопытных телок на выращивании составил: I группа - $295 \kappa 2, I I-289 \kappa 2, I I I-298 \kappa 2, I V-308 \kappa г$ и V-293 кг без статистически достоверной разницы между группами, что позволило сделать вывод об отсутствии инбредной депрессией при разведении скота данного стада с использованием родственного подбора родительских пар. Признано, что селекция телят на увеличение их живой массы при рождении не будет иметь положительного влияния на признак в процессе роста животных с учетом полученной корреляционной связи. В результате изучения воспроизводительной способности доказана иелесообразность получения и использования инбредных животных в стаде, которых можно осеменять на месяи раньше аутбредных. Между аутбредными и инбредными коровами обнаружена значительная дифференциация удоя по первой-третьей лактации, без достоверного преимущества животных, которые были получены тем или иным методом чистопородного разведения. Наиболее высокий удой молока первой лактации имели коровы группь тесного инбридинга (V группа) - 4501 кг, которые превосходили аутбредных на 150 кг и инбредных более низких степеней (II - IV группь) на 191 - 633 кг. Инбредный скот отдаленного, умеренного и близкого степеней инбридинга по второй лактащии производил от 4629 кг до 4719 кг молока при наиболее высоком показателе у коров умеренного степени инбридинга, в то время как аутбреднье коровы производили только 4582 кг. Самый высокий удой по третьей лактации имели коровы умеренного степени инбридинга - 5204 кг, а самые низкие - 3897 кг группы близкого степени инбридинга. Аутбредные коровы по данному признаку превосходили только особей группь близкого инбридинга. Полученные результаты сравнительного анализа хозяйственно полезных признаков аутбредных и инбредных коров и телок белоголовой украинской породы свидетельствуют о возможности использования родственного подбора родительских пар в стаде с иелью повышения эффективности внутрипородной селекции, тиражирование наследственных признаков родоначальника и сохранения исчезающей отечественной породы крупного рогатого скота.

Ключевые слова: скотоводство, белоголовая украинская порода, методы разведения, степень инбридинга, коровы, телки, производительность.

\section{SELECTION EFFICIENCY OF INBRED CATTLE OF UKRAINIAN WHITEHEAD BREED \\ Voitenko S. L., Sydorenko O. V., Institute of Animal Breeding and Genetics} nd. a. M. V. Zubets of NAAS

The stated results of using outbreeding and inbreeding in a selection of cattle of the Ukrainian Whitehead breed, which belongs to the local population and is preserved only in one breeding herd. It was revealed that animals obtained from related breeding are characterized by a sufficiently high level of productivity and normal reproductive qualities. Although outbred and inbred heifers in the process of growth from birth to 18 months of age differed somewhat from each other in live weight, the difference was not statistically significant. In different periods of growth, both outbred and inbred animals had an advantage, indicating the possibility of improving the trait by purebred 
breeding methods. The absolute increase in live weight of experimental heifers on rearing was: Group I-295 kg, II - $289 \mathrm{~kg}, I I I-298 \mathrm{~kg}, \mathrm{IV}-308 \mathrm{~kg}$ and V-293 $\mathrm{kg}$ without a statistically significant difference between the groups, which made it possible to conclude that there was no inbred depression when breeding cattle of a given herd through a related selection of parental pairs. It is recognized that the selection of calves to increase their live weight at birth will not have a positive effect on the trait during the growth of animals, as evidenced by the correlation between them.

As a result of the study of reproductive ability, the expediency of obtaining and using inbred cattle in a herd, which was inseminated almost a month earlier than outbred, was proved. Between outbred and inbred cows, a significant differentiation of milk yield for the first - third lactation was found, without a significant advantage of animals obtained by one or another method of purebred breeding. According to the first lactation, the highest milk yield was observed in cows of the close inbreeding group (group V)-4501 kg, which exceeded the outbred ones by $150 \mathrm{~kg}$ and the lower inbred ones (groups II-IV) by 191 - $633 \mathrm{~kg}$. Inbred cattle with distant, moderate and close degrees of inbreeding at the second lactation had from $4629 \mathrm{~kg}$ to $4719 \mathrm{~kg}$ of milk, with the highest rate in cows of a moderate degree of inbreeding, while outbred cows produced only $4582 \mathrm{~kg}$. Cows of a moderate degree of inbreeding had the highest milk yield in the third lactation - $5204 \mathrm{~kg}$ and the lowest - $3897 \mathrm{~kg}$ of the group of a close degree of inbreeding. Outbred cows for this trait were superior only to individuals of the group of close inbreeding. The results of a comparative analysis of economically useful traits of outbred and inbred cows and heifers of the Ukrainian Whitehead breed indicate the possibility of using a related selection of parental pairs in a herd to increase the efficiency of interbreeding selection, replicate the hereditary traits of the ancestor and preserve the disappearing domestic breed of cattle.

Key words: cattle breeding, Ukrainian Whitehead breed, breeding methods, degree of inbreeding, cows, heifers, productivity. 